\title{
LITERASI DIGITAL DALAM PENGGUNAAN SISTEM INFORMASI PENGENDALIAN TAGIHAN
}

\author{
Intan Ladyta ${ }^{(1)}$,Yosi Handayani ${ }^{(2)}$, dan Roza Puspita ${ }^{(3)}$ \\ Jurusan Manajemen Bisnis, Teknik Mesin, Politeknik Negeri Batam \\ Jl. Ahmad Yani, Batam Centre, Batam 2946I, Indonesia \\ Email: (I) intan.ladyta@yahoo.co.id. (2)yosi@polibatam.ac.id, (3) roza@polibatam.ac.id
}

\begin{abstract}
Badan Pengawasan Keuangan Kepuluan Riau Representative is one of the government institutions which get considerable attention in its financial management. All the money used should be made accountable. Responsibility of each work unit is made using SINTAG application where the result of this input will be compiled into a document of accountability. It would be an update for the treasurer to prepare financial statements. There is a problem especially in the public relation section and administration chief representative in the input process, there is an error in inputting data such as and error in typing or nominal numbers. Such errors would generate not accurate and relevant information for expenditure treasurer in which the inputting results will be material information in financial reporting. Based on the results of the study during an apprenticeship at the Supreme Audit Board of Kepuluan Riau Representative Office, it was found that, digital literacy in using system is one of the main concern, the financial sub-section controls this issue by cross-checking the invoice with the result of input to the SINTAG application in the form of a bill control and pay order.
\end{abstract}

Keywords: The process of inputting, documents of accountability, information, digital literacy

\section{PENDAHULUAN}

Segala kegiatan atau aktivitas perusahaan yang berhubungan dengan bagaimana cara memperoleh pendanaan modal kerja, menggunakan atau mengalokasikan dana, dan mengelola aset yang dimiliki untuk mencapai tujuan utama perusahaan adalah hal yang sangat penting bagi sebuah perusahaan dan juga lembaga pemerintahan. Dalam suatu organisasi,anggaran memegang peran penting dimana anggaran merupakan suatu rencana keuangan yang disusun secara sistematis dalam menunjang terlaksananya program kegiatan suatu organisasi. Seiring dengan adanya tuntutan masyarakat untuk dilakukannya transparansidan akuntabilitas publik, menuntut setiap organisasi pemerintah untuk memperbaiki dan meningkatkan kinerjanya agar lebih berorientasi pada terciptanya good public dan good governance. Pengelolaan anggaran atau keuangan di lembaga-lembaga pemerintahan, perusahaan milik negara (BUMN), perusahaan milik daerah (BUMD), dan berbagai organisasi politik lainnya mendapat perhatian yang lebih besar dari tahun-tahun sebelumnya. Tuntutan akuntabilitas dan transparansi merupakan sebuah kebutuhan yang tidak terelakkan. Salah satunya adalah Badan Pemeriksa Keuangan.

Badan Pemeriksa Keuangan (BPK) merupakan suatu lembaga yang bebas dan mandiri dalam memeriksa pengelolaan dan tanggung jawab keuangan negara diatur dalam UU No 15 Tahun 2006 tentang Badan Pemeriksa Keuangan (Indonesia, 2006). Salah satu perwakilan BPK yang ada di indonesia adalah perwakilan BPK RI 
kepeluan Riau. Pewakilan BPK RI di Tanjungpinang beberapa kali mengalami perubahan nama. Sesuai dengan Keputusan Ketua Badan Pemeriksa Keuangan Republik Indonesia No. 01/K/I-XIII.2/1/2009 tanggal 13 Januari 2009 tentang Nama Perwakilan Badan Pemeriksa Keuangan Republik Indonesia, Perwakilan BPK RI di Tanjungpinang berubah menjadi BPK RI Perwakilan Provinsi Kepulauan Riau. Nama tersebut masih digunakan sampai sekarang. Sebelum Perwakilan BPK RI Perwakilan Provinsi Kepulauan Riau diresmikan, Provinsi Kepulauan Riau dan Provinsi Riau berada dibawah Perwakilan BPK RI Perwakilan Sumatera Utara yaitu Subauditorat Kepulauan Riau, Sumatera Barat dan Riau. Setelah Peresmian BPK RI Perwakilan Provinsi Riau wilayah Provinsi Kepulauan Riau masih masuk wilayah pemeriksaan Pekanbaru. Barulah diresmikan BPK RI Perwakilan Provinsi Kepulauan Riau pada tanggal 29 November 2009 dengan wilayah pemeriksaan yang terdiri dari 2 (dua) Kota dan 4 (empat) Kabupaten.

Badan Pemeriksa Keuangan Perwakilan Provinsi Kepulauan Riau terdapat 7 bidang yang dibawahi oleh Kepala BPK Perwakilan Provinsi Kepulauan Riau. Setiap sub bagian tersebut diberikan anggaran untuk melaksanakan kegiatan-kegiatan tertentu sesuai dengan tugas dan fungsi masing-masing. Setiap sub bagian memiliki bendahara pengeluaran pembantu yang selanjutnya disingkat BPP yaitu orang yang ditunjuk oleh bendahara pengeluaran untuk melaksanakan pembayaran kepada yang berhak guna kelancaran pelaksanaan kegiatan tertentu, Kemudian bendahara pengeluaran dan bendahara pengeluaran pembantu menyiapkan dokumen untuk membuat surat pertanggungjawaban atas anggaran yang digunakannya.

Dalam proses pembuatan surat pertanggungjawaban, setiap sub bagian menggunakan aplikasi SINTAG. Sistem informasi pengendalian tagihan (SINTAG) adalah sebuah aplikasi modern yang berfokus pada efisiensi operasional layanan pengelolaan keuangan terutama pada tingkat kementerian atau lembaga pemerintahan. Aplikasi ini dibangun dan dikembangkan pada tahun 2009 yang diimplementasikan di Kantor Pusat BPK RI. Pada tahun 2011 menyusul Pusdiklat BPK RI juga mengimplementasikan aplikasi SINTAG. Di tahun-tahun berikutnya, SINTAG dijadikan aplikasi standar di Perwakilan-Perwakilan Provinsi BPK RI untuk kegiatan operasional di Subag Keuangan. Aplikasi SINTAG telah resmi terdaftar dalam Daftar Umum Ciptaan pada tahun 2013 sebagai programbuatan indonesia yang dibangun dan dikembangkan oleh sebuah tim dari PT. Nusantara Sistek Integra (NSI). Prinsip-prinsip dasar dalam pengembangan SINTAG adalah melakukan standarisasi proses penyelesaian atau pembayaran dari setiap dokumen tagihan dalam bentuk alur kerja secara sistematis dan menerapkan konsep "Single Entry Principle", sehingga integritas data dapat dijaga serta menghindari penginputan data yang sama lebih dari satu kali (penginputan berulang).

Pengoperasian SINTAG juga dapat melengkapi sistem informasi yang sudah ada (mandatori) dan wajib dioperasikan oleh setiap unit atau satuan kerja di lingkungan kementerian atau lembaga pemerintah lainnya . Dengan demikian, SINTAG dapat meringankan beban pekerjaaan administrasi menjadi lebih efisien dan proses bisnis menjadi lebih sederhana, sehingga informasi factual dan actual yang diperlukan manajemen untuk mengelola dan mengambil keputusan dapat tersedia tepat waktu. Setiap transaksipengeluaran kas yang dilakukan oleh sub bagian, diinput ke dalam aplikasi SINTAG. Surat pertanggungjawaban ini akan diserahkan ke bagian verifikatur atau sub bagian keuangan setiap satu bulan sekali.

Penggunaan aplikasi SINTAGini dapat meringankan beban pekerjaan administrasi menjadi lebih efisien serta dapat memberikan informasi yang dibutuhkan manajemen dalam mengelola dan pengambilan keputusan. Selain itu, aplikasi SINTAG ini dapat menyajikan informasi mengenai berapa anggaran yang sudah direalisasikan dan yang belum terealisasi secara real time karena terhubung dengan jaringan internet. Namun, dalam pelaksanaannya 
masih terdapat staf atau pegawai BPK yang belum mengetahui proses input data belanja ke aplikasi SINTAG. Hal ini tentu dapat menyebabkannya terlambatnya pengumpulan SPJ ke verifikatur atau sub bagian keuangan .

Berdasarkan latar belakang di atas, penulis tertarik untuk melakukan penelitian dengan judul "Literasi Digital Dalam Penggunaan Sistem Informasi Pengendalian Tagihan Pada Badan Pemeriksa Keuangan Perwakilan Provinsi Kepulauan Riau”.

\section{IDENTIFIKASI MASALAH}

Berdasarkan latar belakang di atas, penulis dapat mengidentifikasi masalah antara lain "Kesalahan dalam penginputan data salah satunya seperti menginput mata anggaran atau akun beban yang dapat menyebabkan salah pembebanan serta kesalahan dalam mengetik angka atau nilai nominal.

\section{LANDASAN TEORI}

\section{Standar Operasional Prosedur}

Sailendra (2015), menyatakan bahwa Standard Operational Procedure (SOP) merupakan panduan yang digunakan untuk memastikan kegiatan operasional organisasi atau perusahaan berjalan dengan lancar. Menurut Hartatik (2014) tujuan standaroperasional prosedurantara lain:

1. Untuk menjaga konsistensi tingkat penampilan kinerja atau kondisi tertentu dan kemana petugas dan lingkungan dalam melaksanakan sesuatu tugas atau pekerjaan tertentu.

2. Sebagai acuan dalam pelaks anaan kegiatan tertentu bagi semua pekerja dan supervisor.

3. Untuk menghindari kegagalan atau kesalahan (dengan demikian menghindari dan mengurangi konflik), keraguan, duplikasi serta pemborosan dalam proses pelaksanaan kegiatan.

4. Merupakan parameter untuk menilai mutu pelayanan.

5. Untuk lebih menjamin penggunaan tenaga dan sumber daya secara efisien dan efektif.

6. Untuk menjelaskan alur tugas, wewenang dan tanggung jawab dari petugas yang terkait.

7. Sebagai dokumen yang akan menjelaskan dan menilai pelaksanaan proses kerja bila terjadi suatu kesalahan atau dugaan mal praktek dan kesalahan administratif lainnya, sehingga sifatnya melindungi rumah sakit dan petugas.

8. Sebagai dokumen yang digunakan untukpelatihan.

9. Sebagai dokumen sejarah bila telah dibuat revisi SOP yang baru.

\section{Definisi Sistem}

Beberapa pengertian atau definisi mengenai sistem yang diberikan oleh para ahli s ebagaiberikut: 
a) Mardi (2011:3) adalah “System merupakan suatu kesatuan yang memiliki tujuan bersama memiliki bagian bagian-bagian yang saling berintegrasi satu-sama lain".

b) Supriyati (2012:10), sistem merupakan kumpulan atau unsur dan sub-sub sistem atau komponenkomponen atau prosedur-prosedur baik fisik maupun non-fisik yang mempunyai fungsi dan prosedur tertentu, saling bekerja sama secara harmonis untukmencapai suatu tujuan tertentu.

c) Sutabri (2012), Sistem adalah sekelompok unsur yang erat hubunganny a satu dengan yang lain, yang berfungsi bersama-sama untuk mencapai tujuan tertentu.

d) Bodnar dan Hopwood (2006:3), sistem merupakan sekumpulan sumber daya yang saling terkait yang ingin mencapai suatu tujuan.

\section{Definisi Informasi}

Bodnar dan Hopwood (2006:3), menyatakan informasi merupakan suatu data yang diorganisasi yang dapat mendukung ketepatan pengambilan keputusan. Sutabri (2012) menyatakan bahwa informasi adalah data yang telah diklasifikasikan atau diolah atau diinterpretasikan untuk digunakan dalam proses pengambilan keputusan. Kanisius (2008) merupakan bahan baku informasi, dapat didefinisikan sebagai kelompok teratur simbol-simbol yang mewakili kuantitas, fakta, tindakan, benda dan sebagainya. Sutabri (2012), kualitas dari suatu informasi harus akurat (accurate), tepat waktu (timeliness) dan relevan (relevance) yaitu : akurat, tepat waktu, dan relevan.

\section{Definisi Sistem Informasi}

Bodnar dan Hopwood (2006:6), mengatakan sistem informasi menyiratkan penggunaan teknologi dengan komputer dalam organisasi atau perusahaan yang dapat menyediakan informasi bagi pihak - pihak yang membutuhkan dan pengguna. Menurut Hutahaean (2014) sistem informasi adalah suatu sistem di dalam suatu organisasi yang mempertemukan kebutuhan pengelolaan transaksi harian, mendukung operasi, bersifat manajerial dan kegiatan strategi dari suatu organisasi dan menyediakan pihak luar tertentu dengan laporan-laporan yang dibutuhkan. Jadi, dapat disimpulkan bahwa sistem informasi merupakan gabungan atau kombinasi dari manusia, perangkat keras (hardware), perangkat lunak (software), jaringan, data, kebijakan dan prosedur yang menyimpan, mengumpulkan, memproses atau mengolah yang akan menjadi sebuah informasi yang berguna dalam pengambilan keputusan dan pengontrolan dalam suatu organisasi.

\section{Sistem Informasi Akuntansi}

Salah satu sistem informasi diantara berbagai sistem informasi yang digunakan manajemen dalam mengolah perusahaan adalah sistem informasi akuntansi. Menurut Krismiaji (2010) sis tem informasi akuntansi adalah sebuah sistem yang memproses data dan transaksi guna menghasilkan informasi yang bermanfaat untuk merencanakan, mengendalikan dan mengoperasikan bisnis. Dalam sistem informasi akuntansi, terdapat beberapa siklus pemrosesan transaksi antara lain siklus pendapatan, pengeluaran, produksi, sumber daya manusia, dan siklus pembiayaan atau keuangan. Dengan demikian, sistem informasiakuntansi adalah proses transaksikeuangan dan transaksi non keuangan yang mempengaruhi pemrosesan aspek keuangan yang didalamnya terdapat pemrosesan data, yaitu berupa proses mengumpulkan, mengolah dan melaporkan informasi mengenai aspek keuangan dari kegiatan. 
Sistem informasi akuntansi (SIA) merupakan kumpulan sumber daya, seperti manusia dan peralatan, yang dirancang untuk mengubah data keuangan dan data lainnya kedalam informasi (Bodnar dan Hopwood, 2006: 3). menurut Cushing E. yang diterjemahkan dalam Kosasih (2007:24), unsur-unsur sistem informasi akuntansi terdiri dari :

a. Sumber daya manusia

Sistem informasi akuntansi membutuhkan sumber daya untuk dapat berfungsi. Sumber daya dapat diklasifikasikan sebagai alat, data, bahan pendukung, sumber daya manusia dan dana. Sistem informasi akuntansi pada umumnya diberi nama menurut sumber daya manusia yang digunakan suatu sistem informasi akuntansiakuntansi manual. Jika suatu sistem informasi akuntansi melibatkan penguna komputer dan perlengkapanperlengkapannya dinamai sistem informasi akuntansi dengan komputer (computer based accounting information sistem). Manusia merupakan unsur sistem informasi akuntansi yang berperan dalam pengambilan keputusan dan mengendalikan jalannya sistem informasi akuntansi.

b. Peralatan

Peralatan merupakan unsur sistem informasi akuntansiyang berperan dalam memepercepat pengo lahan data, meningkatkan ketelitian kalkulasi atau perhitungan dan kerapian bentuk informasi.

c. Formulir

Formulir merupakan unsur pokok yang digunakan untuk mencatat semua transaksi yang terjadi. Formulir sering disebut dengan dokumen. Karena dengan formulir peristiwa yang terjadi dalam organisasi direkam (didokumentasikan) diatas secarik kertas.

Ancaman terhadap Sistem Informasi Akuntansi

Fauzi (2017) ancaman atau resiko yang akan mengganggu jalannya sistem informasi akuntansiantara lain:

1. Kehancuran karena bencana alam dan politik. Seperti kebakaran, banjir, gempa bumi, badai angin, peperangan, kerusuhan dan serangan teoris.

2. Kesalahan pada software dan tidak berfungsinya peralatan. Seperti kegagalan hardware, kerusakan pada software, kegagalan sistem operasi dan gangguan listrik.

3. Tindakan tidak disengaja. Kecelakaan yang disebabkan oleh kesalahan manusia sepertipersonal tidak terlatih, kegagalan mengikuti prosedur, penghapusan data karena ketidaktahuan, hilangnya data, kesalahan pada logika sistem atau kesalahan dalam menempatkan data, sistem tidak mampu memenuhi kebutuhan perusahaan.

4. Tindakan sengaja. Seperti sabotase, penipuan melalui komputer, pencurian.

\section{Literasi Digital}

Menurut Eshet-Alkalai (2014: 93) individu diwajibkan untuk menguasai keanekaragaman teknis yang berkembang, kognitif, keterampilan sosiologis untuk melakukan tugas dan memecahkan masalah di lingkungan digital. Keterampilan ters ebut merujuk pada literasi digital yang merupakan salah satu jenis literasi. Literasi digital menurut Gilster (1997: 3) adalah "the ability to understand and use information in multiple formats from a wide variety of sources when it is presented via computers". Literasi digital merupakan kemampuan untuk memahami dan menggunakan informasi dalam berbagai format dari beragam sumber yang disajikan melalui komputer atau secara digital. Jones dan Hafner (2012: 13) menjelaskan bahwa dalam literasi digital tidak hanya melibatkan keterampilan dalam mengoperasikan alat-alat seperti komputer dan ponsel, tetapi juga keterampilan untuk menyesuaikan kemampuan dan keterbatasan alat dalam keadaan tertentu. Dengan literasi digital, diharapkan 
seseorang tidak hanya dapat memahami dan memanfaatkan sumber informasi dalam berbagai format namun juga mampu mengoperasikan perangkat-perangkat yang mendukung. Gilster (1997: 3) mengungkapkan bahwa seseorang berliterasi digital apabila menguasai empat kompetensi inti yaitu pencarian internet, navigasi hypertext, evaluasi konten dan penyusunan pengetahuan

\section{PEMBAHASAN}

\section{Sistem Pertanggung jawaban Uang Muka}

Pembuatan pertanggungjawaban pengeluaran kas di BPK Perwakilan Provinsi Kepri telah menggunakan aplikasi yaitu aplikasi Sistem Informasi Pengendalian Tagihan (SINTAG). Pembuatan pertanggungjawaban uang belanja ini dilakukan oleh pengguna uang muka atau bendahara pengeluaran pembantu yang ditunjuk oleh bendahara pengeluaran yang bertugas untuk memegang uang muka kerja dan melakukan pertanggungjawaban atas uang muka kerja yang digunakannya seperti pembelian alat tulis kantor, jamuan makan atau snack dalam kegiatan, pertemuan atau rapat. Dalam proses penginputan data ke aplikasi SINTAG ini, masing-masing unit kerja diberikan panduan dalam pengerjaannya berupa panduan penggunaan aplikasi SINTAG bukan dari SOP. Berikut alur atau proses dalam penginputan ke aplikasi SINTAG.

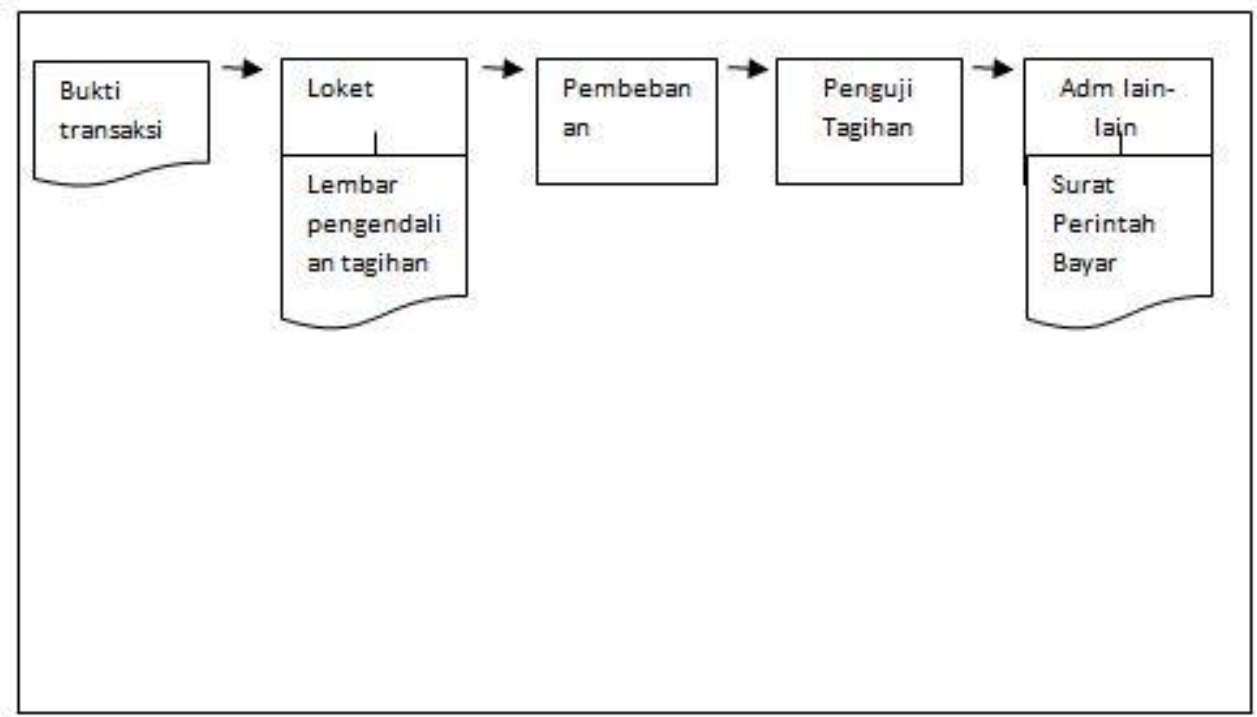

Gambar 1 Proses penginputan data untuk membuat surat

Pertanggungjawaban ke aplikasi

Proses penginputan data yang dilakukan untuk membuat surat pertanggungjawaban menggunakan aplikasi Sistem Informasi Pengendalian Tagihan (SINTAG) adalah sebagaiberikut :

a) Pengguna uang muka atau bendahara pengeluaran pembantu menyiapkan bukti transaksi sepertinota, kuitansi pembelian dan faktur.

b) Loket. Penginputan data ke aplikasi SINTAG yang pertama yaitu bagian loket dengan mengisi jenis tagihan, dari unit, nama penagih, uraian tagihan dan nilai tagihan. Kemudian confirm untuk mencetak lembar pengendalian tagihan.

49 | Intan Ladyta et al. : Literasi Digital Dalam Penggunaan Sistem... 
c) Pembebanan. Setelah penginputan data di bagian loket, dilanjutkan pada bagian pembebanan dengan mengisi nomor registrasi yang didapatkan setelah menginput dibagian loket, lalu memasukkan nomor MataAnggaran Kegiatan (MAK).

Penguji tagihan. Menu atau bagian penguji tagihan dilakukan untuk mengisi tanggal tran saksi. Adm lain-lain. Langkah terakhir dalam penginputan data di aplikasi SINTAG yaitu Adm lain-lain dengan memasukkan nomor registrasi terlebih dahulu, nomor kuitansi di nol kan setelah itu cetak surat perintah bayar (SPBy) dengan mengisi nama dan Nomor Induk Pegawai (NIP) penerima uang muka kemudian print atau cetak.

Kesalahan dalam proses Penginputan Data ke Aplikasi SINTAG

Dalam proses pelaksanaannya, kesalahan biasa terjadi pada penginputan data di bagian loket seperti salah dalam mengetik angka atau nilai nominal yang seharusnya, kemudian kesalahan juga terjadi pada penginputan data di bagian pembebanan berupa kesalahan dalam mengklasifikasikan transaksi ke dalam nomor mata anggaran kegiatan yang seharusnya atau bisa disebut dengan kode akun beban. Kesalahan dalam pengin putan angka tersebut kadang dapat disebabkan oleh bukti transaksi yang kurang jelas serta bendahara yang kurang fokus dan teliti atau kurang mampu dalam mengklasifikasikan transaksi tersebut ke dalam nomor mata anggaran kegiatan yang seharusnya.

Apabila permasalahan ini dibandingkan dengan teori Sistem Informasi Akuntansi menurut Fauzi (2017), kesalahan yang terjadi ini merupakan salah satu ancaman atau exposure dalam sistem informasi akuntansi yaitu tindakan yang tidak disengaja yang dilakukan oleh manusia. Hasil dari penginputan ini akan disebut sebagai dokumen pertanggungjawaban yang nantinya akan menjadi sebuah informasi bagi bendahara pengeluaran untuk membuat laporan keuangan di akhir periode. Menurut Sutabri (2012) disebutkan bahwa karakteristik informasi diantaranya adalah

1. Akurat (accuracy)yaituharus bebas dari kesalahan-kesalahan dan tidak menyesatkan. Akurat juga berarti bahwa informasi harus jelas mencerminkan maksudnya.

2. Relevan (relevance)yaitu informasi tersebut harus mempunyai manfaat untuk pemakaianya.

Jika terjadi kesalahan penginputan data ke aplikasi, tentu akan menghasilkan sebuah informasi yang tidak relevan, benar serta tidak akurat. Sehingga informasi tersebut tidak dapat digunakan sebagai bahan dalam pembuatan laporan keuangan serta informasi tersebut dapat menyesatkan.

Pengendalian dan Solusi Permasalahan

Apabila dokumen pertanggungjawaban tersebut telah selesai diinput lalu selanjutnya diserahkan kepada sub bagian keuangan untuk dilakukan cross check antara kesesuaian bukti transaksi dengan dokumen lembar pengendalian tagihan dan surat perintah bayar yang merupakan hasil inputan dari aplikasi SINTAG. Jika bendahara pengeluaran menemukan ketidaksesuaian, maka dokumen pertanggungjawaban tersebut akan dikembalikan kepada pengguna uang muka atau bendahara pengeluaran pembantu untuk diperbaiki kembali. Dalam memperbaiki kesalahan tersebut, pengguna uang muka akan melakukan pembatalan penginputan di aplikasi SINTAG. Lalu selanjutnya akan menginput kembali dari awal data tagihan tersebut.

Berdasarkan teori Sistem Informasi Akuntansi menurut Fauzi (2017), pengendalian yang dilakukan oleh bendahara pengeluaran sudah sesuai dengan teori yaitu disebutkan bahwa pengendalian internal melakukan tiga fungsi penting yaitu pengendalian untuk pencegahan, pengendalian untuk pemeriksaan, dan pengendalian untuk korektif.Dalam hal ini, bendahara pengeluaran telah melakukan fungsi pengendalian untuk pemeriksaan.Seperti 
yang telah disebutkan tadi bahwa bendahara pengeluaran mengecek kesesuaian antara bukti tran saksi dengan dokumen hasil penginputan.

Secara umum, pengendalian yang dilakukan oleh sub bagian keuangan pada BPK Perwakilan Provinsi Kepulauan Riau terhadap kesalahan penginputan data ini sudah berjalan dengan baik sesuai dengan teori yang ada. Namun, masih saja terdapat kesalahan yang biasa terjadi karena human error yaitu seperti kesalahan pengetikan angka dan mengklasifikasikan transaksi yang terjadi ke dalam nomor mata anggaran kegiatan yang seharusnya. Hal tersebut akan berdampak pada laporan tentang berapa anggaran yang telah terealisasi dan yang belum terealiasasi.

Berdasarkan hasil penelitian penulis selama magang, sebelum dokumen pertanggungjawaban diserahkan kepada sub bagian keuangan sebaiknya pengguna uang muka atau bendahara pengeluaran pembantu harus melakukan cross check terlebih dahulu antara bukti transaksi dan dokumen hasil penginputan ke aplikasiSINTAG. Selain itu, pengguna uang muka juga harus lebih teliti dan lebih fokus dalam menginput data ke sistem aplikasi. Dalam hal ini ketelitian yang tinggi dan pemahaman yang baik harus dimiliki oleh pengguna uang muka selaku staf yang membuat pertanggungjawaban uang belanja. Jika hal itu dimiliki tentu tidak akan terjadi kembali kesalahan dalam pembuatan dokumen pertanggungjawaban.

\section{KESIMPULAN DAN SARAN}

\section{Kesimpulan}

1. Bendahara pengeluaran pembantu atau pengguna uang muka kurang teliti dalam menginput data ke sistem aplikasi seperti salah dalam mengetik angka atau nominal serta salah dalam mengklasifikasikan kegiatan ke nomor mata anggaran yang seharusnya.

2. Pengendalian yang dilakukan oleh Sub bagian keuangan maupun bendahara pengeluaran dalam memeriksa dokumen pertanggungjawaban setiap unit kerja telah sesuaidengan teori yang penulis pelajari.

\section{Saran}

Dari hasil pembahasan yang telah dilakukan oleh penulis tentang proses pembuatan pertanggungjawaban pada sub bagian hubungan masyarakat dan tata usaha kepala perwakilan, maka penulis mencoba memberikan saran yang sekiranya dapat memberikan manfaat bagi instansi dalam melakukan tugasnya lebih lanjut yaitu sebaiknya pengendalian yang dilakukan oleh bendahara pengeluaran maupun sub bagian keuangan juga dilakukan oleh setiap unit kerja lainnya sebelum dokumen diserahkan ke sub bagian keuangan agar ketika terjadi kesalahan dalam penginputan dapat diperbaiki terlebih dahulu. 


\section{DAFTAR PUSTAKA}

Ayuni, Qory Qurratun. 2015. "Literasi Digital Remaja di Kota Surabaya (Studi Deskriptif tentang Tingkat Kompetensi Literasi Digital pada Remaja SMP, SMA dan Mahasiswa di Kota Surabaya” pada Libri-Net Vol. 4 No. 2 September 2015 diakses dari http://journal.unair.ac.id/literasi-digital-remaja-di-kotasurabaya-article-9195-media-136-category-8.html

Bastian, I. (2008). Sistem Akuntansi Sektor Publik. Jakarta: Erlangga.

Bodnar, George H, and William S.Hopwood. 2006. Sistem Informasi Akuntansi, Buku I. Jakarta: Penerbit Salemba Empat.

Chusing, Barry E dan Marshall B. Romney. 2003. Accounting Information System and Business Organization. Addition Wesley Publishing Company Inc. Mass USA.

Eshet-Alkalai, Yoram. 2004. "Digital Literacy: A Conceptual Framework for Survival Skills in The Digital Era" dalam Journal of Educational Multimedia and Hypermedia; 2004; 13, 1; pg. 93. Diunduh dari http://www.openu.ac.il/personal_sites/download/Digital-literacy2004-JEMH.pdf

Fauzi, R. A. (2017). Sistem Informasi Akuntansi(Berbasis Akuntansi). Yogyakarta: Deepublish.

Gilster, Paul. 1997. Digital Literacy. New York: Wiley. Diakses dari https ://openlibrary.org/works/OL2627594W/Digital_literacy

Hartatik, I. P. (2014). Buku Praktis Mengembangkan SDM. Yogyakarta: Laksana.

Hartoko, A. (2011). Menyusun Laporan Keuangan untuk Usaha. Yogyakarta: Multicom.

Hutahaean, J. (2014). Konsep Sistem Informasi. Yogyakarta: Deepublish.

Indonesia. 2006. Undang-Undang No.15 Tahun 2006 Tentang Badan Pemeriksa Keuangan. Jakarta, DKI Jakarta, Indonesia.

Jones, Rodney H, dan Hafner Christoph A. 2012. Understanding Digital Literacies A Practical Introduction. Oxon : Routledge.

Kanisius. (2008). Teknologi Informasi Perpustakaan. Yogyakarta: Kanisius (Anggota IKAPI).

Ketua Badan Pemeriksa Keuangan. (2007). Keputusan Ketua Badan Pemeriksa Keuangan Republik Indonesia No.34/K/I-VIII.3/6/2007 tentang Struktur Organisasi Badan Pemeriksa Keuangan Republik Indonesia . Jakarta.

Krismiaji. (2010). Sistem Informasi Akuntansi. Yogyakarta: Sekolah Tinggi Ilmu Manajemen YPKP. 
Menteri Keuangan Republik Indonesia. 2016. Peraturan Menteri Keuangan Republik Indonesia Nomor 114/PMK.02/2016 Tentang Perubahan Atas Peraturan Menteri Keuangan Nomor 127/PMK.02/2015 Tentang Klasifikasi Anggaran.

Sailendra, A. (2015). Langkah-Langkah Praktis Membuat SOP. Yogyakarta: Trans Idea Publishing.

Supriyati. (2012). Akuntansi Keuangan Bisnis. LABKAT, Bandung.

Sutabri, T. (2012). Analisis Sistem Informasi. Yogyakarta: Andi Offset. 